\title{
A IMPORTÂNCIA DA INTEGRAÇÃO ORTO-PERIO DURANTE O TRATAMENTO ORTODÔNTICO
}

Talita Farias MIKSZA, Aguinaldo Coelho de FARIAS, Juliana KINA, José Ricardo KINA, Francisco Antonio BERTOZ

A hiperplasia gengival $(\mathrm{HG})$ é uma lesão associada à placa bacteriana e fatores secundários, que podem ser medicamentosos, inflamatórios e hormonais, além de fatores de riscos locais, como o tratamento ortodôntico (SOCRANSKY, 1970). O tratamento para a HG baseia-se no controle da placa bacteriana e eliminação ou controle dos fatores de risco. Entretanto, a seqüela deve ser tratada por técnicas cirúrgicas periodontais, como a gengivoplastia (BOLLEN, 2008). No caso clínico apresentado, ressaltamos a importância da integração entre a Ortodontia e a Periodontia durante o tratamento ortodôntico. Um paciente leucoderma, de 15 anos de idade, apresentava hiperplasia gengival nos arcos dentários superior e inferior, nas faces vestibulares e linguais, devido ao aumento de placa bacteriana, causado pelo uso de aparelho ortodôntico fixo associado à alteração hormonal. Após o controle da placa bacteriana, por meio de raspagem, alisamento e orientação de higienização bucal, a correção da seqüela hiperplásica foi realizada através da gengivoplastia, que recuperou o contorno normal da gengiva marginal, possibilitando 0 prosseguimento do tratamento ortodôntico. A multidisciplinaridade entre o ortodontista e o periodontista é importante para que, em conjunto, se estabeleça um programa de tratamento, fornecendo estética e preservando a saúde dos tecidos periodontais.

Palavras-chave: Ortodontia; Periodontia; Gengivite. 